\title{
Studies in Canadian Literature
}

\section{Études en littérature canadienne}

\section{A Hell of a Voice Reflections on an Ongoing Conversation}

\section{Paul Chafe}

Volume 43, Number 2, 2018

URI: https://id.erudit.org/iderudit/1062927ar

DOI: https://doi.org/10.7202/1062927ar

See table of contents

Publisher(s)

University of New Brunswick, Dept. of English

ISSN

0380-6995 (print)

1718-7850 (digital)

Explore this journal

Cite this document

Chafe, P. (2018). A Hell of a Voice: Reflections on an Ongoing Conversation.

Studies in Canadian Literature / Études en littérature canadienne, 43(2).

https://doi.org/10.7202/1062927ar

All Rights Reserved ( Studies in Canadian Literature / Études en littérature canadienne, 2018
This document is protected by copyright law. Use of the services of Érudit (including reproduction) is subject to its terms and conditions, which can be viewed online.

https://apropos.erudit.org/en/users/policy-on-use/
This article is disseminated and preserved by Érudit.

Érudit is a non-profit inter-university consortium of the Université de Montréal, Université Laval, and the Université du Québec à Montréal. Its mission is to promote and disseminate research.

https://www.erudit.org/en/ 


\title{
A Hell of a Voice: \\ Reflections on an Ongoing Conversation
}

\author{
Paul Chafe
}

I

WAS STRUGGLING TO WRITE this essay for Herb Wyile until two very fortuitous events helped me find the words I need to say about my friend and colleague. The first event was one of my students arriving at my office door in person-from-Porlock fashion utterly derailing my train of thought. Unlike Coleridge's unwanted visitor, however, this student did not so much remove me from a moment of inspiration as bring me to one. Knowing that I am a Newfoundlander, my student greeted me with his best mainland attempt at the following:

"Whaddaya at?"

It is a Newfoundland and Labrador colloquialism misunderstood often by outsiders to mean either "What are you doing?" or "How are you doing?" It is, of course, both and neither. As a salutation it functions as a sort of Newfoundland Shibboleth - a test of the authenticity of the Newfoundlander being posed the question. For, as any Newfoundlander or Labradorian who has passed the test can tell you, there are but two acceptable responses to the above greeting:

1. "Nothing." (Granted, there are variations on this, such as "Nothing, b'y" or, for the particularly verbose, "Nothing b'y, what are you at?")

2. "This is it."

It is the second response that comes to mind these days whenever I take stock of my current professional and scholarly situation.

What am I at?

This is it.

And it is Herb Wyile's fault I am still at it.

At the time I am writing this I am a 41-year-old sessional instructor at Ryerson University teaching between five and six classes per term. While teaching duties take up much of my time, I still manage to remind myself each year that I am a Canadianist by participating in conferences, publishing at least one scholarly article, and writing a spate of reviews on the latest literature from Newfoundland and 


\section{SCL/ÉLC}

Labrador. I teach during the spring term as well, so the amount of work time I can commit each year exclusively to research and publication is limited usually to two months in the summer. A few years ago I decided this was not enough time to produce meaningful contributions each year, so I would henceforth commit my professional efforts entirely to pedagogy.

This was a decision spurred primarily by some of the successes I experienced as a lecturer - specifically the flipped lecture delivery method I employ in my first-year writing courses. It was a decision driven also by the bleak prospects facing a Canadian literature scholar. There have been few postings in recent years, and while I applied for all of them, my efforts had gleaned only a handful of on-campus interviews. I was fishing in two ponds and it was time to cut bait in one and commit to the other. I decided to stick with the pond in which I had managed at least a few bites.

All that was left for me was to inform Herb I was getting out of the Atlantic Canadian literature game. He had been a friend and a mentor for years as well as a stalwart supporter who never failed to produce a glowing reference letter when called upon. For several years Herb and I had been meeting annually at conferences like ACCUTE or Atlantic Canada Studies, sometimes giving papers on the same panel. I was always delighted to see him and we chatted about what we were working on, what we were reading, what we were teaching, and, of course, the Montreal Canadiens. Those meetings were more than enough to fuel a years-long correspondence via email — with the occasional phone call - through which we kept the conversation going on our papers and projects and (mostly my) prospects. Herb had put a considerable amount of effort into my career, and he deserved an explanation as to why I was suddenly switching focus. I wanted to tell him about my decision in person and I did so at the Atlantic Canada Studies Conference at the University of New Brunswick in 2014, which at the time I thought would be the last conference I would attend with the express purpose of talking about Atlantic Canadian literature.

Herb sympathized with my situation and accepted my decision. More than most, Herb knew what it was like to be a long-serving sessional, he knew what it was like to work under the stress that comes with precarious employment, and he knew how difficult it was to contribute meaningfully in one field while so much of one's time is occupied deliv- 
ering courses in another. He listened with interest to my project and my plans to dedicate my time to reviving and restructuring the delivery of first-year writing courses. As always, he was positive and encouraging. We talked until the panels for the next session were about to begin, and as we both walked into the classroom, Herb turned to me and said, "You're a hell of a voice to lose, Paul."

I do not think Herb knew the effect that statement had on me or maybe he did. It was at once a valuation and a validation of my work and a reminder of the importance of the ongoing conversation of which these contributions were a part. I recognized each paper on the panel Herb and I watched after our conversation as a part of a continuing dialogue - not only contributions but also invitations for others to respond and otherwise advance the analysis. As Herb and I posed questions to the panelists I was reminded of how much I loved this, of how much I needed to hear these voices, and of how much I needed to have my voice included in this conversation. It is a hell of a community to lose.

As I was trying to write about this community of scholars and artists to which I am connected almost exclusively through Herb, the second fortuitous event occurred: Herb's daughter, Hannah, texted me a picture of her father and I chatting in Paddy's Pub just after the completion of the Thomas H. Raddall Symposium at Acadia University. Herb holding forth, I the eager audience, and just outside the frame, either physically or metaphorically, are the members of this wonderful community Herb knew I could not leave; writers and educators I respect and now, thanks to Herb, I can count as friends: Alexander MacLeod, Peter Thompson, Andrea Schwenke Wyile, Cynthia Sugars, David Creelman, Tony Tremblay, Andrea Cabajsky, Thomas Hodd, Lisa Moore, Ed Riche, and so many others. Herb understood the panic that was driving my decision to leave, but he knew also that this community and my place in it meant more to me than any professional or financial reward it would or would not offer. My heart aches to look at this picture but I am so happy I decided to remain a part of this community and have that moment and so many others.

So, what am I at? This is it. And I am at this because it keeps me connected to a vibrant literature, the artists who produce it, and the scholars who elevate it. I am at this because of the joy I receive from participating in this dialogue and introducing other, newer participants 


\section{SCL/ÉLC}

to the books and essays of a wonderful scholar to whom their work is in many ways a response. I am at this because it lets me keep talking to my friend, Herb.

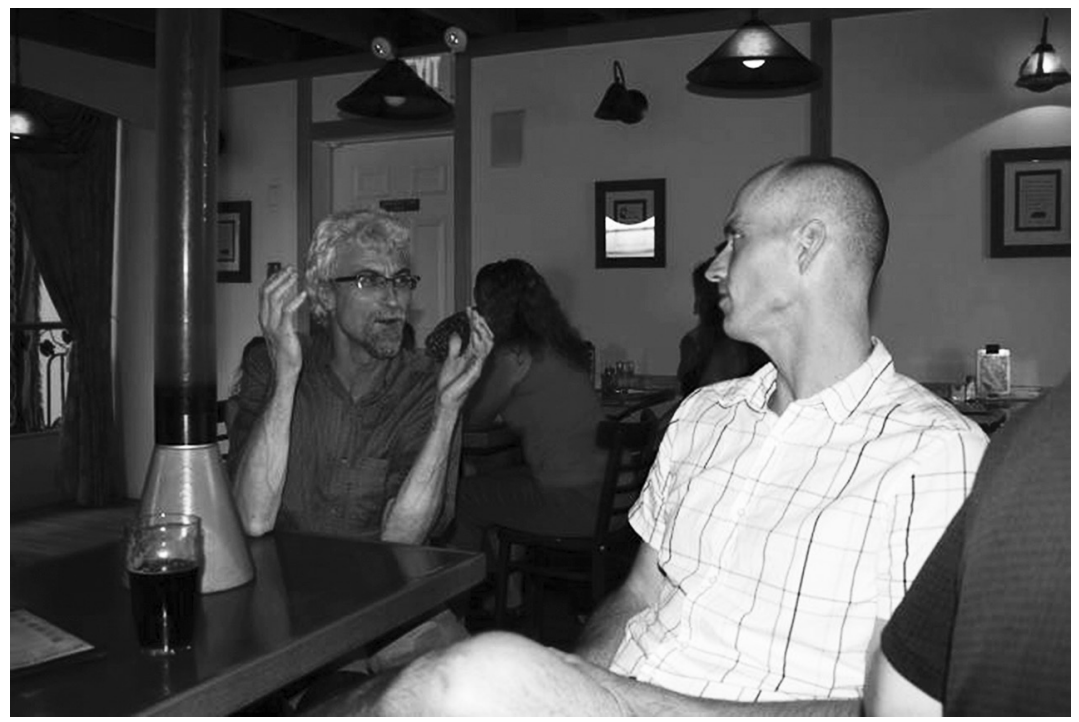

Herb Wyile and Paul Chafe in conversation at Paddy's Pub upon completion of the Eighth Thomas Raddall Symposium. Wolfville, Nova Scotia, 7 July 2013. Photo credit: Hannah Wyile. 